\title{
TOBACCO TAXATION IN THE EUROPEAN UNION
}

\author{
SIJBREN CNOSSEN
}

CESIFO WORKING PAPER NO. 1718

CATEgory 1: Public Finance

MAY 2006

An electronic version of the paper may be downloaded

- from the SSRN website:

www.SSRN.com

- from the RePEc website:

www.RePEc.org

- from the CESifo website:

www.CESifo-group.de 


\title{
TOBACCO TAXATION IN THE EUROPEAN UNION
}

\begin{abstract}
Later this year, the European Commission has to submit a report to the Council of Ministers and the European Parliament with its views on tobacco tax policy in the EU. A 2004 publication issued by the Commission expressed the beliefs that tobacco consumption should be controlled by increasing tobacco excises and that harmonization should proceed on the basis of specific rates. This article reviews and evaluates EU tobacco tax policies. It supports the move towards specific taxation, but notes that there are conceptual and empirical limits to excessively high tobacco taxes. Smokers appear to pay their way and cigarette smuggling is a growing menace to health and revenue objectives.
\end{abstract}

JEL Code: H2, H8.

Keywords: tobacco taxation, European Union.

\author{
Sijbren Cnossen \\ Maastricht University \\ CPB Netherlands Bureau for Economic Policy Analysis \\ Tapijtweg 7 \\ 2597 KG The Hague \\ The Netherlands \\ cnossen@few.eur.nl
}

April 2006

The author is grateful to Peter Kooiman, Judith Payne and two anonymous referees from FinanzArchiv for their comments on an earlier version of this paper. 
Smoking has been declared a deadly disease. According to a report with the telling title Tobacco or Health in the European Union, financed by and prepared for the European Commission (2004), ${ }^{1}$ smoking is the single largest cause of avoidable death in the European Union (EU), killing 625.000 smokers each year (one in seven of all deaths) and involving gross costs estimated at between 1.04 and 1.39\% of the EU's GDP in 2000. As the backbone of a strong 'smoking intervention policy', the report recommends that '[r]egular increases in tobacco taxes should be an implicit part of government efforts at EU and Member State level as these underpin other tobacco-control measures. ${ }^{2}$

Next to the level, the structure of tobacco taxation is considered important. Should tobacco excises be levied at a fixed amount per quantity (specific rate), a fixed percentage of the product's retail price (ad valorem rate), or some combination of these rates? Indeed, thus far, the appropriate balance between specific and ad valorem taxation has governed much of the debate on the harmonization of tobacco excises in the EU. Although the EU's directives still have detailed rules regarding this balance, the 2004 report believes that '[d]ifferences in tax rates should be harmonised on the basis of specific rates as opposed to ad valorem.'

In 2006, the European Commission will have to submit its next four-year report on tobacco taxation to the Council of Ministers and the European Parliament. ${ }^{3}$ In anticipation of this report, this article reviews and evaluates current tobacco tax regimes in the EU. Section 2 lists the main elements of the agreed excise duty structure, called acquis communautaire, and highlights the diversity of cigarette tax rates and structures across the EU. Since the choice between specific and ad valorem taxation is a bone of contention, section 3 summarizes the theoretical findings on this issue. Subsequently, section 4 reviews the evidence on the question of whether smokers pay for the costs they impose on others. Next, section 5 dwells on revenue and tax rate issues, while section 6 deals with bootlegging and smuggling. Section 7 summarizes the main tax policy points that emerge from the analysis.

\footnotetext{
${ }^{1}$ The report elaborates on an earlier joint study by the World Bank (WB) and the World Health Organization (WHO) (Jha and Chaloupka, 2000). In the WB/WHO study's wake, the WHO promoted the worldwide adoption of a Framework Convention on Tobacco Control, which was subsequently endorsed by all EU Member States.

${ }^{2}$ This and the quotation in the next paragraph are from p. 230 of the report. The other tobacco-control measures should include better and more widely publicized research into the consequences of smoking, comprehensive bans on the promotion and advertising of tobacco products, bans on specified tobacco outlets (internet sales and vending machines), universal smoke-free work and public places, and the development of cessation strategies.

${ }^{3}$ The last report was submitted in 2001 (European Commission, 2001).
} 
The current tobacco tax structures in the EU have evolved over 35 years in a series of political compromises and exigencies, with reforms often triggered by the prospective accession of new Member States. The latest Council directive (Council of the European Union, 2002) prescribes the following agreed tax measures:

- Member States impose a cigarette excise duty consisting of a specific and an ad valorem component. Effective July 1, 2006, the minimum total excise duty must be $€ 64$ per thousand cigarettes (€1.28 per pack of twenty). This requirement applies to all cigarettes.

- Furthermore, the minimum total level of excise taxation on the Most Popular Price Category (MPPC) of cigarettes in each Member State should be $57 \%$ of the tax-inclusive (excise plus VAT) retail sale price. ${ }^{4}$ States are exempt from this requirement if the total excise duty on MPPC cigarettes is $€ 101$ or more per thousand cigarettes (€2.02 per pack of twenty).

- Member States can choose to set a minimum level of excise duty on all cigarettes at $100 \%$ of the level of the excises on the MPPC.

- There must be an element of both specific and ad valorem tax in the cigarette excise duty charged by Member States, with the specific element no less than $5 \%$ and no more than $55 \%$ of the total tax on the MPPC, including the VAT (which is identical in effect to the ad valorem excise duty).

- Sharply reduced rates - measured in terms of the price or weight of tobacco - apply to (a) fine-cut or rolling tobacco: $36 \%$ of the tax-inclusive retail price or €32 per kg; (b) cigars and cigarillos: $5 \%$ of the tax-inclusive retail price or $€ 11$ per 1000 items or per kg; and (c) other smoking tobacco: 20\% of the tax-inclusive retail price or $€ 20$ per $\mathrm{kg}$. There is no prescribed specific component for these tobacco products.

- All tobacco products are subject to the standard VAT rate, which should not be less than $15 \%$.

- Intra-EU cross-border duty-paid shopping allowances are the following cigarettes: 40 packs; cigars: 200 items; cigarillos: 400 items; and smoking tobacco: $1 \mathrm{~kg}$.

- In addition to these tax measures, the European Commission has issued rules regarding health warnings on tobacco packages, as well as restrictions on advertisements, sponsorships, and smoking in public places.

The discussion in this article focuses mainly on cigarettes, which account for nearly $90 \%$ of total tobacco product sales. Figure 1 shows that the acquis communautaire for cigarettes permits a wide range of total tax levels (specific

\footnotetext{
${ }^{4}$ The brand of cigarettes that represents the MPPC in each Member State differs across Member States, depending on consumer tastes, market conditions, excise duty arrangements, and other factors.
} 
and ad valorem excises plus VAT) and excise duty structures (specific vs. ad valorem taxes), as well as retail selling prices, throughout the EU.

Figure 1

Taxes on Cigarettes in the European Union

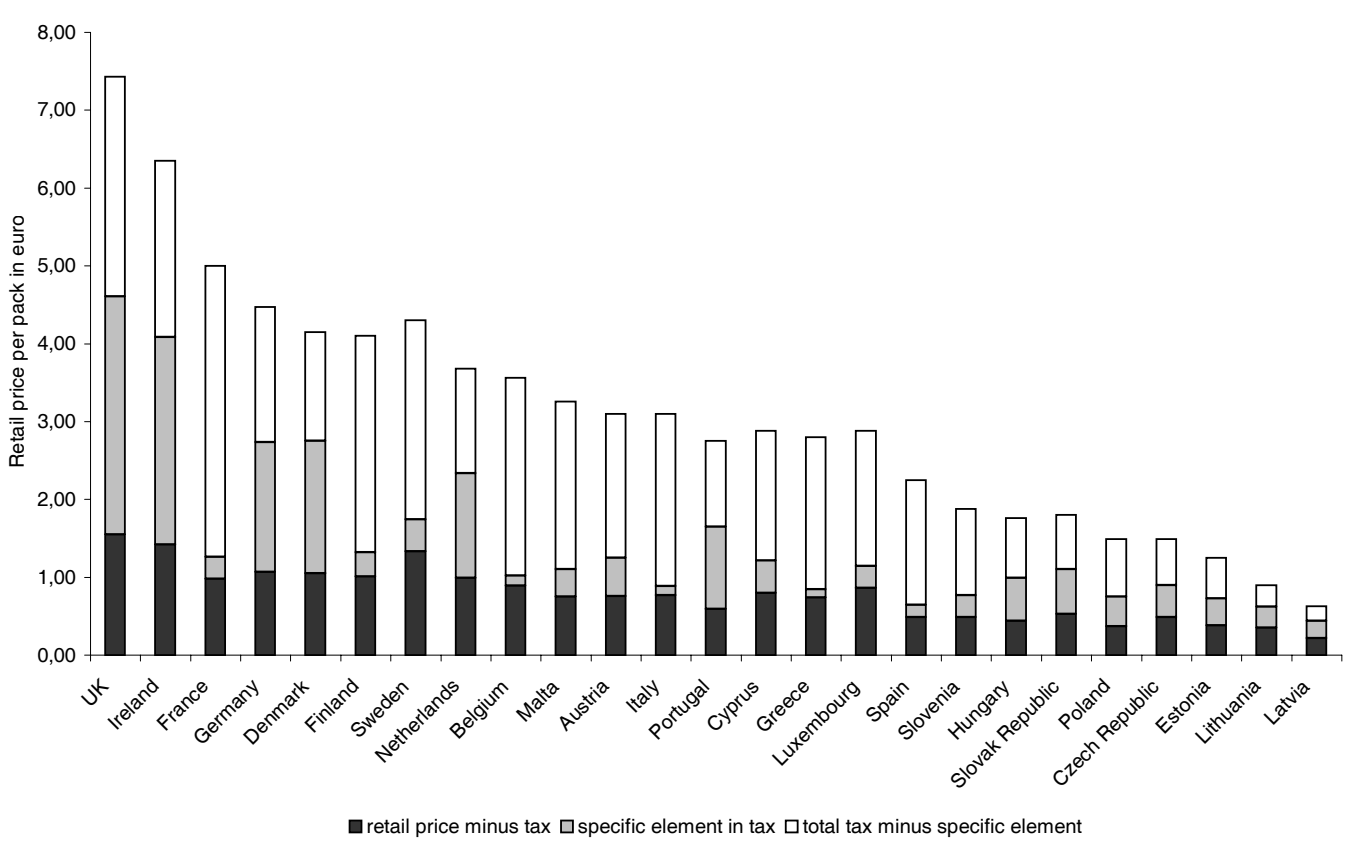

Source: Table 1. Member States are ranked by decreasing amount of total tax per pack of cigarettes. Taxes have been calculated by reference to the retail sale price of the Most Popular Price Category (MPPC) of cigarettes in each Member State.

In the 'old' Member States (EU-15; see Table 1), total taxes on MPPC cigarettes, at, on average, in excess of $300 \%$ of the pre-tax retail price, are the highest on any single product in the world; by comparison, the standard VAT rate is, on average, $19.8 \%$ in these states. Furthermore, while relative total tax burdens of, on average, $75 \%$ of the retail price do not vary greatly between most Member States, there are substantial differences in the absolute amounts of total tax burdens and retail prices of MPPC cigarettes. The UK, for example, levies $€ 5.88$ tax per pack of 20 cigarettes (of which $€ 3.01$ is from the specific rate), but Spain only $€ 1.76$ (of which $€ 0.16$ is from the specific rate). Not surprisingly, retail prices are $€ 7.43$ and $€ 2.25$ per pack, respectively - a difference of $€ 5.18$ per pack or $€ 0.26$ per stick. Clearly, harmonization still has some way to go.

All old EU Member States meet the minimum total excise requirement of €64 per thousand cigarettes. In Denmark and Sweden, the total excise duty is less than $57 \%$ of the retail selling price, but then the overall excise burden in these countries is more than $€ 101$, which supersedes the $57 \%$ requirement. Of the 'new' Member States (EU-10; see Table1), Cyprus and Malta comply with the acquis communautaire and Hungary with the 57\% criterion, but the other new 
Table 1

Statistics on Smoking in the European Union

(value figures in Euro)

\begin{tabular}{|c|c|c|c|c|c|c|c|}
\hline $\begin{array}{l}\text { Member } \\
\text { State }^{\mathrm{a}}\end{array}$ & $\begin{array}{c}\text { Retail } \\
\text { price per } \\
\text { pack of } 20 \\
\text { MPPC }^{b} \\
\end{array}$ & $\begin{array}{c}\text { Total tax } \\
\text { per pack } \\
\text { (incl. VAT) }\end{array}$ & $\begin{array}{l}\text { Specific } \\
\text { excise } \\
\text { as } \% \text { of } \\
\text { total tax }\end{array}$ & $\begin{array}{c}\text { Total tax } \\
\text { revenue per } \\
\text { capita } \\
\text { (incl. VAT) } \\
\end{array}$ & $\begin{array}{l}\text { Consump- } \\
\text { tion per } \\
\text { capita } \\
\text { (packs) }\end{array}$ & $\begin{array}{l}\text { Smokers: } \\
\text { men-women } \\
\text { in } \%\end{array}$ & $\begin{array}{l}\text { Smuggling } \\
\text { as \% of } \\
\text { domestic } \\
\text { sales } \\
\end{array}$ \\
\hline EU-15 & 3.99 & 3.03 & 27 & 277 & 117 & $33-24$ & \\
\hline UK & 7.43 & 5.88 & 52 & 192 & 44 & $26-24$ & na \\
\hline Ireland & 6.35 & 4.93 & 54 & 333 & 66 & $28-26$ & 4 \\
\hline France & 5.00 & 4.02 & 7 & 238 & 47 & $36-25$ & 2 \\
\hline Germany & 4.47 & 3.40 & 49 & 204 & 89 & $37-28$ & 10 \\
\hline Denmark & 4.15 & 3.10 & 55 & 242 & 77 & $30-24$ & na \\
\hline Finland & 4.10 & 3.09 & 10 & 148 & 48 & $26-19$ & na \\
\hline Sweden & 4.30 & 2.97 & 14 & 125 & 40 & $16-19$ & 2 \\
\hline Netherlands & 3.68 & 2.69 & 50 & 160 & 47 & $33-27$ & 8 \\
\hline Belgium & 3.56 & 2.67 & 5 & 200 & 68 & $33-22$ & 7 \\
\hline Austria & 3.10 & 2.34 & 21 & 208 & 89 & $32-26$ & 15 \\
\hline Italy & 3.10 & 2.33 & 5 & 191 & 84 & $31-17$ & 12 \\
\hline Portugal & 2.75 & 2.16 & 49 & 129 & 89 & $31-15$ & na \\
\hline Greece & 2.80 & 2.06 & 5 & 254 & 157 & $51-39$ & 8 \\
\hline Luxembourg & 2.88 & 2.02 & 14 & 1353 & 707 & $39-26$ & 7 \\
\hline Spain & 2.25 & 1.76 & 9 & 175 & 109 & $39-25$ & 15 \\
\hline EU-10 & 1.73 & 1.25 & 36 & 95 & 82 & $40-20$ & \\
\hline Malta & 3.26 & 2.51 & 14 & 207 & 74 & $30-21$ & na \\
\hline Cyprus & 2.88 & 2.08 & 20 & 192 & 87 & $39-8$ & na \\
\hline Slovenia & 1.88 & 1.39 & 20 & 155 & 115 & $28-20$ & na \\
\hline Hungary & 1.76 & 1.32 & 42 & 95 & 76 & $42-29$ & 5 \\
\hline Slovak Rep & 1.80 & 1.27 & 45 & 52 & 42 & $48-32$ & 3 \\
\hline Poland & 1.49 & 1.12 & 34 & 48 & 79 & $39-23$ & 15 \\
\hline Czech Rep & 1.49 & 1.00 & 41 & 88 & 110 & $38-23$ & 7 \\
\hline Estonia & 1.25 & 0.87 & 40 & 60 & 82 & $45-18$ & 16 \\
\hline Lithuania & 0.90 & 0.55 & 50 & 24 & 43 & $44-12$ & 30 \\
\hline Latvia & 0.63 & 0.41 & 53 & 27 & 114 & $49-13$ & 39 \\
\hline EU averages & 3.09 & 2.32 & 30 & 204 & 103 & $36-22$ & \\
\hline
\end{tabular}

Sources:

-Retail prices, tax rates, and specific elements (2006): European Commission (2006).

-Consumption and tax revenues (2004): industry sources and own calculations.

-Percentage smokers (2002-03): www.ash.org.uk (6 January 2006).

-Smuggling (1995): table 15.3 in Merriman et al. (2000).

Notes:

${ }^{a}$ EU-15 and EU-10 are each ranked by decreasing amount of total tax per pack of 20 cigarettes.

${ }^{b}$ MPPC is Most Popular Price Category of cigarettes in each Member State on which basis the total tax has been calculated. 
states do not; they will have to increase current excise duty levels on cigarettes by between $18 \%$ (Slovenia) and 310\% (Latvia) to do so.

The preference for a predominantly specific or ad valorem duty is about evenly divided among Member States. When both rates are expressed as percentages of the VAT-exclusive retail price, 12 mainly northern tobacco-importing Member States have a predominantly specific excise duty structure while 13 mainly southern tobacco-growing Member States have a preference for the ad valorem excise duty. Notable exceptions to the north-south contrast are Belgium, Finland, Luxembourg, and Sweden, where the ad valorem rate is higher than the specific rate, and Portugal, where the specific rate dominates the ad valorem rate.

\section{Specific vs. Ad Valorem Rates}

What is the appropriate balance between specific and ad valorem taxation $?^{5}$ In practice, the balance is not dictated by theoretical considerations about product quality, external costs, or revenue, but mainly by protectionist sentiments. The home-grown tobaccos of the southern Member States are cheaper than the higher-quality American blends that the northern Member States import for their consumers, as reflected in the differences in retail prices minus taxes (in other words, production and distribution costs) in Figure 1: the pre-tax price ranges from $€ 0.22$ (Latvia) to $€ 1.55$ (UK) per pack, and from $20 \%$ (France) to $39 \%$ (Lithuania) of the retail price. Since a specific rate tends to shrink relative price differences between low-cost and high-cost brands, whereas an ad valorem regime does not, the latter is more propitious to southern European producers, mainly Italy and Greece. ${ }^{6}$

Since the European Commission has expressed an interest in giving more weight to the specific rate, it may be instructive to review briefly the theoretical arguments regarding the choice between specific and ad valorem taxation. ${ }^{7}$ In a perfectly competitive market for a homogeneous good, the choice is irrelevant: any specific tax could be replaced by its percentage equivalent with no effect on consumer and producer prices or on government revenue.

\footnotetext{
${ }^{5}$ For a review of the theoretical arguments, see especially Keen (1998). The conflict over the appropriate rate structure is reflected in the tobacco tax rate structures of the various Member States as well as the acquis communautaire: the $57 \%$ requirement favors harmonization on the basis of the ad valorem rate, but the $€ 64 / 1000$ sticks minimum excise burden favors harmonization on the basis of the specific rate.

${ }^{6}$ Tobacco is also the most heavily subsidized crop per hectare under the Common Agricultural Policy (CAP). The EU spends nearly $€ 1$ billion annually on tobacco subsidies $-2.3 \%$ of the CAP budget and $1.1 \%$ of the Commission budget. The EU has decided to phase out the production subsidies by 2010 and replace them by lump-sum payments and subsidies to finance restructuring programs. See European Commission (2004).
}

${ }^{7}$ This and the next section are adapted from Cnossen and Smart (2005). 
In an imperfectly competitive market, however, quality levels between similar excisable products, such as cigarettes, differ widely: someone who smokes knows that there are large differences in quality between a Virginia and two sticks of sawdust. In such a market, a common specific tax rate reduces relative price differences between low-quality and high-quality brands, while a common ad valorem rate does not. Standard optimal tax considerations would therefore seem to argue for ad valorem taxation - relative prices would be unchanged, and consumers would continue to choose brand on the basis of cost rather than tax differences. ${ }^{8}$

These arguments apply to competitive markets in which the set of quality levels on offer is given exogenously. With imperfect competition, however, firms' incentives to raise price and to distort quality may be quite different under specific and ad valorem taxation. In the case of a monopolist, for example, specific taxation increases marginal costs by a fixed amount, whereas ad valorem taxation acts as a proportional tax on costs, together with a proportional (lump-sum) tax on monopoly profits. By taxing marginal revenue, ad valorem taxation, $t_{a}$, increases the firm's perceived demand elasticity by the multiplier $1 /\left(1-t_{a}\right)$ and so diminishes incentives for the firm to raise price above marginal cost. Thus one might expect consumer prices to be lower under ad valorem than under specific taxation. Indeed, it is possible to show, in the monopoly case, that replacing a specific tax, $t_{s}$, by its ad valorem equivalent, $t_{a}=t_{s} / p$, causes consumer prices to fall and tax revenue and monopoly profits to rise (Skeath and Trandel, 1994). So everyone gains from ad valorem taxation except the public health advocate. ${ }^{9}$

Just as ad valorem taxation seems to induce firms to cut prices, it also creates a clear incentive to downgrade product quality (Barzel, 1976), because the multiplier effect of ad valorem taxation makes improvements in product quality more expensive for the firm. The cost of carbon filters, for example, which purify the tobacco of tar and other harmful substances, is subject to the multiplier effect. Likewise, ad valorem taxation reduces incentives to invest in advertising, promotion, and other demand-enhancing fixed costs of production.

\footnotetext{
${ }^{8}$ Of course, the tax would still have income effects that might induce consumers to choose lower-quality brands, but so would a non-distortionary lump-sum tax. The theory of optimal taxation implies that a uniform percentage tax on a subset of commodities is desirable only under restrictive conditions on preferences (Atkinson and Stiglitz, 1980), but in this context those restrictions seem plausible.

${ }^{9}$ In the Cournot model of an oligopoly industry, the story is largely the same: a shift to ad valorem taxation will reduce prices and increase government revenues. In this case, however, industry profits may fall, as competition among firms intensifies. A further, testable, implication of the theory is that the pass-through of tax increases to consumer prices should be greater under specific than under ad valorem taxation (Delipalla and Keen, 1992). Indeed, there is some evidence that specific taxes in the EU are more likely to be 'over-shifted' (consumer prices rise by more than the tax) than ad valorem taxes (Delipalla and O'Donnell, 2001).
} 
In contrast, specific taxation does not directly distort manufacturers' decisions to invest in product quality. ${ }^{10}$

In short, the choice between specific and ad valorem taxation depends on whether the primary aim of the policy is to discourage consumption or to raise revenue and on whether improvements in product quality are deemed desirable or not. Furthermore, if the goal of policy is to reduce consumption, there is some tension between the tendency of specific taxes to lead to higher consumer prices and the tendency of ad valorem taxes to discourage investments in quality that keep consumers 'hooked'. (On the other hand, if the goal is to reduce consumption damage, ad valorem rates have the drawback that they discourage expensive filters.) On balance, the solution is likely to be ad valorem taxation at a higher equivalent rate to achieve the desired level of consumer prices, and with concomitant gains for government treasuries.

The Pigouvian perspective leads to a very different conclusion, however - the damage caused by smoking is, at any point in time, independent of the price at which cigarettes are sold, so that correction of externalities favors specific over ad valorem taxation. ${ }^{11}$ Furthermore, other, more immediate, considerations might govern the choice of tax structure. Thus, a specific tax can be imposed at the manufacturer's or importer's stage where it is easiest to collect, whereas, under a system of free trade prices, an ad valorem levy must be collected at the retail stage if trade distortions and tax avoidance are to be avoided. In the EU, of course, most Member States circumvent this issue by determining the ad valorem excise by reference to agreed retail prices, making the excise a specific tax as long as cigarette producers do not negotiate new retail prices with the excise tax authorities. ${ }^{12}$

\section{Do Smokers Pay Their Way?}

In recent years, the controversy about specific vs. ad valorem taxation has largely been overtaken by a heated debate about the costs that smokers impose on society. Smoking is a primary cause of lung cancer, emphysema, and chronic bronchitis, and a major cause of heart disease and stroke. The economic costs - related primarily to the expense of treating smoking-related illnesses, as well as the well-being and market earnings that are lost as a consequence of

\footnotetext{
${ }^{10}$ However, specific taxation may induce consumers to opt for higher-quality brands, if the degree of tax shifting is independent of product quality. In support of this view, Sobel and Garrett (1997) find that specific tax increases in US states are associated with significant declines in the market share of generic brands.
}

${ }^{11}$ An economic counter-argument is that the share of specific in total taxation should be smaller when the marginal cost of public funds is higher and the importance of excise duties for generating revenue correspondingly greater. To some extent, this reasoning is consistent with the ad valorem excise element in EU tobacco tax structures.

\footnotetext{
${ }^{12}$ An incidental, if welcome, side effect of this practice is that it weakens the argument that the value of a specific excise erodes with inflation. After all, inflation would compel producers to approach the excise authorities with a proposal for a new retail price.
} 
smoking-related illnesses and death - are relevant to public policy if external, i.e. imposed on others, rather than internal, i.e. borne privately by the smoker (e.g. through higher health insurance contributions). ${ }^{13}$ Along with information failures, i.e. lack of knowledge about addiction and health risks, the external costs establish a case for government intervention through taxation, as well as, or instead of, through regulation and education.

Various researchers have attempted to provide empirical estimates of the gross (public and private) external costs of smoking. The essence of the most common approach is to use healthcare utilization rates to forecast the incremental health expenditures for the current generation of smokers, make some additions for the healthcare costs associated with environmental or 'second-hand' tobacco smoke, ${ }^{14}$ and then divide the total amount by the number of packs of cigarettes currently consumed, to arrive at an estimate of the (average) Pigouvian tax rate. Since the externalities from tobacco consumption may well be almost constant across each unit consumed, the average tax rate should closely approximate the marginal tax rate.

On the basis of a careful review of a large number of studies, Lightwood et al. (2000) conclude that estimates of gross external costs range from 0.1 to $1.1 \%$ of GDP in high-income countries. The higher estimates are found in countries where healthcare costs account for a relatively large share of GDP. As regards EU Member States, research in the UK for 1985-86 estimated gross costs at between 0.08 and $0.13 \%$ of GDP (Maynard et al., 1987), while gross costs in Finland for 1995 were estimated at $0.17 \%$ of GDP (Pekurinen, 1999).

Smokers tend to live shorter lives than non-smokers, however, which saves on pension payments and healthcare costs of age-related diseases. ${ }^{15}$ From an economic point of view, therefore, it is net costs, which assess all government social security expenditures over a lifetime, that should be the focus of analysis. ${ }^{16}$ Although Lightwood et al. (2000) conclude that the majority of the

13 The distinction between public and private healthcare expenditures seems irrelevant if private health insurers do not successfully control moral hazard by smoking clients. In this case, virtually all smoking-related healthcare expenditures are properly classified as external costs that should be internalized through Pigouvian taxation.

\footnotetext{
${ }^{14}$ Viscusi (2002) indicates that the evidence on the potential health risks of second-hand smoke is not as compelling as the evidence on risks of primary tobacco smoke, which are among the most well-established health risks. It is also argued that much second-hand smoke is experienced within the family home. Accordingly, such costs should be internalized by the smoker, either through altruism or through explicit negotiations among family members (Manning et al., 1989). This is not entirely plausible, however, if the family members are very young or still unborn.

${ }^{15}$ Obviously, this does not mean that death is an economically desirable event. Rather, as Warner et al. (1995) point out, it simply means that as long as early death reduces the extra social costs in the form of social benefits and pensions, smokers should receive a 'credit' for the associated savings.

${ }^{16}$ It is sometimes argued that the output, income, and employment generated by the tobacco industry must be viewed as benefits to the community at large, but this proposition rests on the highly unlikely assumptions that, in the absence of smoking, the money spent on cigarettes would not be spent on other products and that the resources used in producing cigarettes would have no alternative uses. This having been said, short-run adjustment costs from industry downsizing would arise, of course.
} 
cross-section studies reviewed by them indicate that the net costs of smoking are small but positive, there are notable exceptions in the literature. For the Netherlands, for instance, Barendregt et al. (1997) calculated the length of time it takes for the cost savings from smoking to be balanced by the increased costs from the longer life expectancies of non-smokers. Their results imply that smoking reduces net healthcare costs (using a discount rate of up to 5\%). Similarly, a study for Finland (Pekurinen, 1992) concluded that smoking could involve net healthcare cost savings (using a $4 \%$ discount rate). ${ }^{17}$

This evidence is striking, because it means that government measures to reduce smoking through higher taxes would seem to be a form of paternalism on which economics has little to say. After all, the principle of consumer sovereignty implies that a rational person who weighs up all the costs and benefits of his actions should be free to smoke as long as he is fully informed about the consequences of his choice and does not impose costs on others. Admittedly, as has been pointed out, the rationality condition ceases to apply if smokers are illinformed about the consequences of smoking, act myopically in choosing to consume an addictive drug (Peck et al., 2000), or behave in a dynamically inconsistent fashion (Gruber and Koszegi, 2001) by discounting costs and benefits in the near-term future to a greater extent than those in the long term. ${ }^{18}$

In the main, however, the rationality hypothesis is the cornerstone of economic analysis. Accordingly, on economic grounds, the role of taxation in curtailing tobacco use at current levels of excise duties and VATs does not seem very strong in the EU, because smokers seem to pay their way and probably more than that. This economic conclusion, of course, may not satisfy public health advocates who believe that less smoking is always better. But this position rests on the questionable assumption that governments know what is best for people. On balance, the line should probably be drawn at providing information on the

\footnotetext{
17 In a very thorough and influential study for the US, Manning et al. (1989) conclude that the net costs of smoking are US $\$ 0.15$ per pack and the gross costs US $\$ 0.42$ (future costs discounted at $5 \%$ ). The net costs rise to US $\$ 0.38$ if all lives lost to passive smoking and smoking-related fires are treated as external costs rather than assumed to be in the family and taken into account by the smoker. The last amount approximately equals the sum of the state and federal excise and sales taxes of US $\$ 0.37$ per pack. Accordingly, the authors conclude that smokers probably pay their way. In an updated version of the Manning et al. study, Viscusi (1995) found that total taxes on cigarettes exceeded the net external costs of smoking in the US, because the financial savings from premature mortality in terms of lower nursing-home costs and retirement pensions exceeded the higher medical care and life insurance costs generated. The results of these studies, however, are sensitive to the choice of the discount rate at which the net present value of future costs is estimated. At $0 \%$ and $10 \%$ discount rates, the net external costs in the Manning et al. study are US\$0.91 and US $\$ 0.24$ per pack, respectively.

${ }^{18}$ In support of this view, Gruber and Mullainathan (2005) provide evidence that higher cigarette taxes increase smokers' self-reported happiness.
} 
consequences of smoking, banning smoking in public places, and discouraging smoking by the young. 19

\section{Revenue and Tax Rate Issues}

Taxation of cigarettes (and other tobacco products) generates widely varying amounts of tax revenue in different Member States, largely (although not entirely) attributable to differences in the level of taxation. Table 1 indicates that tobacco taxes range from €24 per capita in Lithuania to €333 in Ireland and $€ 1353$ in Luxembourg, which snatches a considerable part of the tax base of its neighboring Member States (see below). These figures include the VAT, which is imposed on the excises as well as on the cost of tobacco products. ${ }^{20}$ On average, the old Member States collect considerably more on a per-capita basis than the new Member States, with the exception of the small island economies, Malta and Cyprus, and Slovenia. Obviously, per-capita tax revenue is also correlated with per-capita consumption. As the table shows, a greater percentage of men than women smoke, except in emancipated Sweden, and on average the percentage of male smokers is higher in new Member States than in old states.

A standard economic justification for the imposition of high tobacco taxes is that they minimize the efficiency costs of raising a given amount of revenue, because the elasticity of demand for cigarettes is low. What evidence is there that this 'inverse elasticity' rule indicates above-average taxes on tobacco? Viscusi (1992, 2002) provides a review of 41 studies on the effect of cigarette prices on the demand for cigarettes. Thirty-one of these studies are for the US, for which the estimated elasticities of demand are clustered in the range- 0.4 to -1.0 . Nine of the studies are for the UK, where the estimated elasticity range is from -0.1 to -0.8 , but most studies yield estimates around -0.5 or -0.6 . As expected, the long-run elasticity is higher than the short-run elasticity and young people are more price-responsive than older smokers. Viscusi (2006) points out that the tobacco price elasticity is not unlike similar estimates for stationery, legal services, automobile repairs, and newspapers and magazines, as well as a wide variety of food products, ranging from chickens to bananas. On balance, therefore, the price elasticity of tobacco demand is not so low that significantly higher-than-average tax rates are warranted on inverse elasticity grounds.

\footnotetext{
${ }^{19}$ For a cogent defense of a liberal yet compassionate attitude, see The Economist (1996). It should also be pointed out that the non-fiscal control measures have a regulatory effect with a 'tax-equivalent' value, which should, broadly speaking, be deducted from the Pigouvian tax that would be indicated in the absence of the regulatory policies.

${ }^{20}$ It is often argued that the VAT should be left out of consideration, because its imposition would not affect the price of tobacco relative to other consumer goods. This would be correct if the excises reflected the social cost of tobacco use, but to the extent that this is not the case, the VAT on the amount of the excises over the social cost represents an additional tax. If the social costs of smoking were negligible (see above), the effective VAT rate, expressed as a percentage of pre-tax price, would be $54 \%$ instead of $15 \%$ (assuming that the excises amounted to $57 \%$ of the tax-inclusive retail price).

11
} 
As regards the structure of the excise duties across different tobacco products, there is considerable substitution away from high-taxed cigarettes towards lowtaxed roll-your-own (fine-cut) tobacco. Over the period 2002-04, the weighted average quantity of cigarettes released for consumption decreased by $10 \%$, while the quantity of roll-your-own tobacco (which accounts for some one-tenth of tobacco product sales) increased by $20 \%{ }^{21}$ Cigarettes contain some 0.75 grams of tobacco. Allowing for cost differences, presumably roll-your-own tobacco should be taxed at two-thirds of the €64/1000 sticks excise duty level on cigarettes or at $€ 57$ per $\mathrm{kg}$, three-fourths higher than the current agreed minimum rate of $€ 32$ per $\mathrm{kg}$.

Another issue concerns the prescribed calculation of the tax burden by reference to the MPPC concept. This concept, necessitated by the use of high ad valorem excise duties on cigarettes, appears ill-defined and subject to manipulation (Oxford Economic Forecasting, 2004). Administrative problems and uncertainty arise, because the MPPC can be taken from any time period in the two years prior to the date that the tax is calculated, while the MPPC category can represent as little as $14 \%$ of total market volume. When the market leader in any Member State raises its MPPC price, this may force tax and price increases of competitive brands - an abuse of dominant position, arguably in violation of Article 82 of the EU Treaty.

Similarly, the 57\% criterion has perverse effects below the $€ 101$ level. A Member State with a volatile cigarette market where the MPPC changes from the top of the price range to the bottom can be conforming to the minimum excise one day and be in breach of the acquis communautaire the next, without having made any change to its tax rates and with virtually no change in the market situation. Adoption of a single specific rate eventually would obviate the need for the anachronistic MPPC concept and the 57\% criterion.

Finally, it should be noted that tobacco taxes are highly discriminatory and regressive, more so than any other tax. In the EU, only $36 \%$ of men and $22 \%$ of women pay tobacco taxes (see Table 1). Regressivity should not be an issue if tobacco taxes serve as a proxy for social costs that should be reflected in the price of cigarettes: the poor, just like the rich, should pay for the costs they impose on others. But if the social cost argument does not cut much ice (see above), then regressivity is an issue that should be taken into consideration. Proportionately, the poor spend a higher share of their income on cigarettes than the rich, assuming that the prevalence of smoking is the same. As a group, however, the poor smoke more than the rich, which tends to exacerbate the regressivity problem across income classes. In fact, smoking is becoming increasingly concentrated in lower classes - variously defined by income, education, occupation, or social class. While the poor were the last to pick up smoking, they are also the last to quit. (See Bobak et al. (2000).)

\footnotetext{
${ }^{21}$ Although fine-cut tobacco sales account on average for a small percentage of the total tobacco market, in some Member States, e.g. Belgium and the Netherlands, their share is relatively high. In turn, this means that per-capita consumption figures in Table 1 are lower than they otherwise would be. 
Furthermore, there are worrisome tobacco tax enforcement problems in the EU. The high levels of tobacco taxation in most Member States, as well as the large differences between them (along with the very large increases in international trade and passenger movements), have become fertile breeding grounds for bootlegging (the purchase of duty-paid tobacco products in excess of crossborder shopping allowances in low-tax states for consumption in high-tax states) and smuggling (the purchase and consumption of tobacco products on which no duty has been paid).

Luxembourg is a prime example of a major bootlegging country due to the much higher total tax rates on tobacco products in neighboring states. If annual consumption per adult in Luxembourg were the same as average consumption in Belgium, France, and Germany (see Table 1), then only $10 \%$ of cigarettes bought in the duchy would be consumed there. Bootlegging is also a problem between Poland and Germany (the price differential is €2.98; see Table 1), Finland and Estonia (€2.85), and Greece and Bulgaria (€1.56) (Joossens and Raw, 2000). Bootlegging of roll-your-own tobacco is a serious problem for the UK which has a high specific excise of $€ 157.61$ per kg compared with Belgium which levies only a moderate ad valorem excise of $37.55 \%$. Only three out of every 10 packets of hand-rolling tobacco consumed in the UK are duty-paid (House of Commons Treasury Committee, 2005), in spite of a sizable increase in the cross-border shopping allowance from $1 \mathrm{~kg}$ to $3 \mathrm{~kg}$.

The most serious problem facing EU Member States, however, is not bootlegging but large-scale organized smuggling of tobacco products on which no duty has been paid at all. As Table 1 indicates, cigarette smuggling, as a percentage of domestic sales, has moved into double figures in Poland and the Baltic States as well as in Austria, Spain, Italy, and Germany. ${ }^{22}$ In 2004, HM Customs and Excise (House of Commons Treasury Committee, 2005) estimated that the share of illicit cigarettes in the domestic market of the UK was some $15 \%$, two-thirds of which was accounted for by smuggling. Many illegal shipments originate in China (the world's largest producer of counterfeit cigarettes), where cigarettes are not controlled regarding carcinogens (arsenic, cadmium, lead) and hazardous remnants of pesticides or excessive levels of tar and nicotine.

\footnotetext{
${ }^{22}$ Cnossen and Smart (2005) estimate the population-weighted average of smuggled cigarettes as a percentage of EU consumption in 1995 at about $8.9 \%$. It is highly likely that this figure has to be revised upwards due to the enormous growth in trade and passenger movements since 1995. In the press, sharply higher figures than shown in Table 1 have been reported for Finland, France, Germany, and Hungary.
} 
The main conclusion of this review of tobacco taxation in the EU is that the externality argument seems to be less persuasive than appears to be the case at first sight. Also, above-average taxation of tobacco on inverse elasticity grounds is difficult to defend. Furthermore, smuggling, by organized crime, is a serious problem. In short, there are conceptual and empirical limits to excessively high levels of tobacco taxation.

The main issues can be summed up as follows:

- Apparently, the European Commission favors a 'smoking intervention policy' rather than an economic approach that has regard to net social costs and distributional concerns. This view seems defensible if market imperfections, such as information failures, are involved, but smells of paternalism with regard to rational tobacco consumers. The problem of environmental tobacco smoke can best be tackled by a ban on smoking in public places.

- The Commission recommends higher taxes on tobacco, even though the tax burden on cigarettes, at $300 \%$ of the pre-tax retail price, is already the highest on any single product in the world. Clearly, the high tax burden promotes smuggling, which in turn undermines health policies and revenue. Although the case for increasing cigarette excises further is weak, an argument can be made for aligning the excise duties on other tobacco products with those on cigarettes.

- The harmonization of tobacco duties, promoted by the Commission, would reduce bootlegging (not smuggling), but violates the subsidiarity principle. Interestingly, harmonization is not pursued in the US (or in other federal countries), where cigarette taxes range from US\$0.86 in Virginia to US\$2.48 in New Jersey (Cnossen and Smart, 2005).

- In a break with the policy pursued thus far, a report published by the Commission now favors specific over ad valorem excise rates as the best means to promote its smoking intervention policy and tax harmonization goals. Specific rates would not require agreement between governments and producers on prescribed retail prices, which violate the free market principle and which are susceptible to manipulation. This would obviate the need for the MPPC concept and the 57\% criterion. Interestingly, ad valorem excise duties are not applied in the US or other non-EU industrialized countries. A drawback of specific rates is that their yield does not increase with rises in the consumer price index; accordingly, automatic adjustment should be provided for by law.

In conclusion, the European Commission seems well-advised to pursue specific tobacco taxation and to confine the ad valorem element to the VAT. Rate increases beyond the current level of $€ 64 / 1000$ sticks appear inadvisable if the baby is not to be thrown away with the bath water. Perhaps the new Member States should be granted longer adjustment periods. Further harmonization does 
not sit well with subsidiarity, although it would mitigate the bootlegging problem.

\section{References}

Atkinson, A., and Stiglitz, J. E. (1980), Lectures on Public Economics, McGraw-Hill, Maidenhead.

Barendregt, J. J., Bonneux, L., and van der Maas, P. J. (1997), The health care costs of smoking, New England Journal of Medicine 337, 1052-7.

Barzel, Y. (1976), An alternative approach to the analysis of taxation, Journal of Political Economy 84, 1177-97.

Bobak, M., Jha, P., Nguyen, S., and Jarvis, M. (2000), Poverty and smoking, in P. Jha and F. Chaloupka (eds), Tobacco Control in Developing Countries, Oxford University Press on behalf of the World Bank and the World Health Organization, Oxford.

Cnossen, S., and Smart, M. (2005), Taxation of tobacco, in S. Cnossen (ed.), Theory and Practice of Excise Taxation: Smoking, Drinking, Gambling, Polluting, and Driving, Oxford University Press, Oxford.

Council of the European Union (2002), Directive of 12 February amending directives 92/79/EEC, 92/60/EEC and 95/59/EEC as regards the structure and rates of excise duty applied on manufactured tobacco, Official Journal L046 (16 February).

Delipalla, S., and Keen, M. J. (1992), The comparison between ad valorem and specific taxation under imperfect competition, Journal of Public Economics 49, 351-67.

— and O’Donnell, O. (2001), Estimating tax incidence, market power and market conduct: the European cigarette industry, International Journal of Industrial Organization 19, 885-908.

European Commission (2001), Report from the Commission to the Council and the European Parliament on the Structure and Rates of Excise Duty Applied on Cigarettes and Other Manufactured Tobacco Products, COM (2001) 133 final (14 March), Brussels.

- (2004), Tobacco or Health in the European Union: Past, Present and Future, The Aspect Consortium, Brussels.

— (2006), Excise Duty Tables, Part III - Manufactured Tobacco, January, Directorate General Taxation and Customs Union, Brussels.

Gruber, J., and Koszegi, B. (2001), Is addiction 'rational'? Theory and evidence, Quarterly Journal of Economics 116, 1261-303.

- and Mullainathan, S. (2005), Do cigarette taxes make smokers happier, Advances in Economic Analysis \& Policy 5, 1-43.

House of Commons Treasury Committee (2005), Excise Duty Fraud, Fourth Report of Session 2004-05 (15 March), Stationery Office, London.

Jha, P., and Chaloupka, F. (eds), (2000), Tobacco Control in Developing Countries, Oxford University Press on behalf of the World Bank and the World Health Organization, Oxford.

Joossens, L., and Raw, M. (2000), How can cigarette smuggling be reduced? British Medical Journal 321, 947-50.

Keen, M. J. (1998), The balance between specific and ad valorem taxation, Fiscal Studies 19, $1-37$.

Lightwood, J., Collins, D., Lapsley, H., and Novotny, T. E. (2000), Estimating the costs of tobacco use, in P. Jha and F. Chaloupka (eds), Tobacco Control in Developing Countries, Oxford University Press on behalf of the World Bank and the World Health Organization, Oxford.

Manning, W. G., Keeler, E. B., Newhouse, J. P., Sloss, E. M., and Wasserman, J. (1989), The taxes of sin: do smokers and drinkers pay their way? Journal of the American Medical Association 261, 1604-9.

Maynard, A., Hardman, G., and Whelan, A. (1987), Measuring the social costs of addictive substances, British Journal of Addiction 82, 701-6.

Merriman, D., Yurekli, A., and Chaloupka, F. J. (2000), 'How big is the worldwide cigarettesmuggling problem?', in P. Jha and F. Chaloupka (eds), Tobacco Control in Developing Countries, Oxford University Press on behalf of the World Bank and the World Health Organization, Oxford. 
Oxford Economic Forecasting (2004), Cigarette Taxation: Issues for EU Accession Countries, International Tax Notes, Special Reports (March 22).

Peck, R., Chaloupka, F. J., Jha, P., and Lightwood, J. (2000), A welfare analysis of tobacco use, in P. Jha and F. Chaloupka (eds), Tobacco Control in Developing Countries, Oxford University Press on behalf of the World Bank and the World Health Organization, Oxford.

Pekurinen, M. (1992), Economic Aspects of Smoking: Is There a Case for Government Intervention in Finland? VAPK Publishing, Helsinki.

- (1999), The Economic Consequences of Smoking in Finland 1987-1995, Health Services Research Ltd., Helsinki.

Sobel, R.S., and Garrett, T.A. (1997), Taxation and product quality: new evidence from generic cigarettes, Journal of Political Economy 105, 880-7.

Skeath, S. E., and Trandel, G. A. (1994), A Pareto comparison of ad valorem and unit taxes in noncompetitive environments, Journal of Public Economics 53, 53-71.

The Economist (1996), Tobacco on trial (11 May).

Viscusi, W. K. (1992), Smoking: Making the Risky Decision, Oxford University Press, New York.

- (1995), Cigarette taxation and the social consequences of smoking, in J. M. Poterba (ed.), Tax Policy and the Economy, MIT Press, Cambridge, MA.

- (2002), Smoke Filled Rooms: A Post-Mortem on the Tobacco Deal, University of Chicago Press, Chicago.

- (2006), Principles of cigarette taxation, in S. Cnossen (ed.), Excise Tax Policy and Administration in Southern African Countries, UNISA Press, Pretoria.

Warner, K. E., Chaloupka, F. J., Cook, P. J., Manning, W. C., Newhouse, J. P., Novotny, T. E., Schelling, T. C., and Townsend, J. (1995), Criteria for determining an optimal cigarette tax: the economist's perspective, Tobacco Control 4, 380-6. 


\section{CESifo Working Paper Series}

(for full list see www.cesifo-group.de)

1653 Axel Dreher and Friedrich Schneider, Corruption and the Shadow Economy: An Empirical Analysis, January 2006

1654 Stefan Brandauer and Florian Englmaier, A Model of Strategic Delegation in Contests between Groups, January 2006

1655 Jan Zápal and Ondřej Schneider, What are their Words Worth? Political Plans and Economic Pains of Fiscal Consolidations in New EU Member States, January 2006

1656 Thiess Buettner, Sebastian Hauptmeier and Robert Schwager, Efficient Revenue Sharing and Upper Level Governments: Theory and Application to Germany, January 2006

1657 Daniel Haile, Abdolkarim Sadrieh and Harrie A. A. Verbon, Cross-Racial Envy and Underinvestment in South Africa, February 2006

1658 Frode Meland and Odd Rune Straume, Outsourcing in Contests, February 2006

1659 M. Hashem Pesaran and Ron Smith, Macroeconometric Modelling with a Global Perspective, February 2006

1660 Alexander F. Wagner and Friedrich Schneider, Satisfaction with Democracy and the Environment in Western Europe - a Panel Analysis, February 2006

1661 Ben J. Heijdra and Jenny E. Ligthart, Fiscal Policy, Monopolistic Competition, and Finite Lives, February 2006

1662 Ludger Woessmann, Public-Private Partnership and Schooling Outcomes across Countries, February 2006

1663 Topi Miettinen and Panu Poutvaara, Political Parties and Network Formation, February 2006

1664 Alessandro Cigno and Annalisa Luporini, Optimal Policy Towards Families with Different Amounts of Social Capital, in the Presence of Asymmetric Information and Stochastic Fertility, February 2006

1665 Samuel Muehlemann and Stefan C. Wolter, Regional Effects on Employer Provided Training: Evidence from Apprenticeship Training in Switzerland, February 2006

1666 Laszlo Goerke, Bureaucratic Corruption and Profit Tax Evasion, February 2006

1667 Ivo J. M. Arnold and Jan J. G. Lemmen, Inflation Expectations and Inflation Uncertainty in the Eurozone: Evidence from Survey Data, February 2006 
1668 Hans Gersbach and Hans Haller, Voice and Bargaining Power, February 2006

1669 Françoise Forges and Frédéric Koessler, Long Persuasion Games, February 2006

1670 Florian Englmaier and Markus Reisinger, Information, Coordination, and the Industrialization of Countries, February 2006

1671 Hendrik Hakenes and Andreas Irmen, Something out of Nothing? Neoclassical Growth and the 'Trivial' Steady State, February 2006

1672 Torsten Persson and Guido Tabellini, Democracy and Development: The Devil in the Details, February 2006

1673 Michael Rauber and Heinrich W. Ursprung, Evaluation of Researchers: A Life Cycle Analysis of German Academic Economists, February 2006

1674 Ernesto Reuben and Frans van Winden, Reciprocity and Emotions when Reciprocators Know each other, February 2006

1675 Assar Lindbeck and Mats Persson, A Model of Income Insurance and Social Norms, February 2006

1676 Horst Raff, Michael Ryan and Frank Staehler, Asset Ownership and Foreign-Market Entry, February 2006

1677 Miguel Portela, Rob Alessie and Coen Teulings, Measurement Error in Education and Growth Regressions, February 2006

1678 Andreas Haufler, Alexander Klemm and Guttorm Schjelderup, Globalisation and the Mix of Wage and Profit Taxes, February 2006

1679 Kurt R. Brekke and Lars Sørgard, Public versus Private Health Care in a National Health Service, March 2006

1680 Dominik Grafenhofer, Christian Jaag, Christian Keuschnigg and Mirela Keuschnigg, Probabilistic Aging, March 2006

1681 Wladimir Raymond, Pierre Mohnen, Franz Palm and Sybrand Schim van der Loeff, Persistence of Innovation in Dutch Manufacturing: Is it Spurious?, March 2006

1682 Andrea Colciago, V. Anton Muscatelli, Tiziano Ropele and Patrizio Tirelli, The Role of Fiscal Policy in a Monetary Union: Are National Automatic Stabilizers Effective?, March 2006

1683 Mario Jametti and Thomas von Ungern-Sternberg, Risk Selection in Natural Disaster Insurance - the Case of France, March 2006

1684 Ken Sennewald and Klaus Waelde, "Itô's Lemma" and the Bellman Equation for Poisson Processes: An Applied View, March 2006 
1685 Ernesto Reuben and Frans van Winden, Negative Reciprocity and the Interaction of Emotions and Fairness Norms, March 2006

1686 Françoise Forges, The Ex Ante Incentive Compatible Core in Exchange Economies with and without Indivisibilities, March 2006

1687 Assar Lindbeck, Mårten Palme and Mats Persson, Job Security and Work Absence: Evidence from a Natural Experiment, March 2006

1688 Sebastian Buhai and Coen Teulings, Tenure Profiles and Efficient Separation in a Stochastic Productivity Model, March 2006

1689 Gebhard Kirchgaessner and Silika Prohl, Sustainability of Swiss Fiscal Policy, March 2006

1690 A. Lans Bovenberg and Peter Birch Sørensen, Optimal Taxation and Social Insurance in a Lifetime Perspective, March 2006

1691 Moritz Schularick and Thomas M. Steger, Does Financial Integration Spur Economic Growth? New Evidence from the First Era of Financial Globalization, March 2006

1692 Burkhard Heer and Alfred Maussner, Business Cycle Dynamics of a New Keynesian Overlapping Generations Model with Progressive Income Taxation, March 2006

1693 Jarko Fidrmuc and Iikka Korhonen, Meta-Analysis of the Business Cycle Correlation between the Euro Area and the CEECs, March 2006

1694 Steffen Henzel and Timo Wollmershaeuser, The New Keynesian Phillips Curve and the Role of Expectations: Evidence from the Ifo World Economic Survey, March 2006

1695 Yin-Wong Cheung, An Empirical Model of Daily Highs and Lows, March 2006

1696 Scott Alan Carson, African-American and White Living Standards in the $19^{\text {th }}$ Century American South: A Biological Comparison, March 2006

1697 Helge Berger, Optimal Central Bank Design: Benchmarks for the ECB, March 2006

1698 Vjollca Sadiraj, Jan Tuinstra and Frans van Winden, On the Size of the Winning Set in the Presence of Interest Groups, April 2006

1699 Martin Gassebner, Michael Lamla and Jan-Egbert Sturm, Economic, Demographic and Political Determinants of Pollution Reassessed: A Sensitivity Analysis, April 2006

1700 Louis N. Christofides and Amy Chen Peng, Major Provisions of Labour Contracts and their Theoretical Coherence, April 2006

1701 Christian Groth, Karl-Josef Koch and Thomas M. Steger, Rethinking the Concept of Long-Run Economic Growth, April 2006 
1702 Dirk Schindler and Guttorm Schjelderup, Company Tax Reform in Europe and its Effect on Collusive Behavior, April 2006

1703 Françoise Forges and Enrico Minelli, Afriat's Theorem for General Budget Sets, April 2006

1704 M. Hashem Pesaran, Ron P. Smith, Takashi Yamagata and Liudmyla Hvozdyk, Pairwise Tests of Purchasing Power Parity Using Aggregate and Disaggregate Price Measures, April 2006

1705 Piero Gottardi and Felix Kubler, Social Security and Risk Sharing, April 2006

1706 Giacomo Corneo and Christina M. Fong, What's the Monetary Value of Distributive Justice?, April 2006

1707 Andreas Knabe, Ronnie Schoeb and Joachim Weimann, Marginal Employment Subsidization: A New Concept and a Reappraisal, April 2006

1708 Hans-Werner Sinn, The Pathological Export Boom and the Bazaar Effect - How to Solve the German Puzzle, April 2006

1709 Helge Berger and Stephan Danninger, The Employment Effects of Labor and Product Markets Deregulation and their Implications for Structural Reform, May 2006

1710 Michael Ehrmann and Marcel Fratzscher, Global Financial Transmission of Monetary Policy Shocks, May 2006

1711 Carsten Eckel and Hartmut Egger, Wage Bargaining and Multinational Firms in General Equilibrium, May 2006

1712 Mathias Hoffmann, Proprietary Income, Entrepreneurial Risk, and the Predictability of U.S. Stock Returns, May 2006

1713 Marc-Andreas Muendler and Sascha O. Becker, Margins of Multinational Labor Substitution, May 2006

1714 Surajeet Chakravarty and W. Bentley MacLeod, Construction Contracts (or "How to Get the Right Building at the Right Price?’), May 2006

1715 David Encaoua and Yassine Lefouili, Choosing Intellectual Protection: Imitation, Patent Strength and Licensing, May 2006

1716 Chris van Klaveren, Bernard van Praag and Henriette Maassen van den Brink, Empirical Estimation Results of a Collective Household Time Allocation Model, May 2006

1717 Paul De Grauwe and Agnieszka Markiewicz, Learning to Forecast the Exchange Rate: Two Competing Approaches, May 2006

1718 Sijbren Cnossen, Tobacco Taxation in the European Union, May 2006 